\title{
Miłosz i ptaki
}

Magdalena Śniedziewska

TEKSTY DRUGIE 2018, NR 2, S. 235-254

DOI: 10.18318/td.2018.2.15

Miłosz to poeta dwoisty: romantyczny, a zarazem programowo klasyczny. Bardzo zmysłowy, a jednocześnie intelektualny. Chodzimy po lesie, on wszystkie ptaki nazywa po imieniu, ja rozglądam się za jakimś pniakiem, żeby usiąść i napić się wina, a on tam pohukiwał, wołał ptaki - cały wydany naturze.

Zbigniew Herbert ${ }^{1}$

Znawcy twórczości Czesława Miłosza niejednokrotnie pisali o jego stosunku do natury. Aleksander Fiut podkreśla, że szczególna więź, jaka łączyła poetę z przyrodą, „w znacznym stopniu uformowała jego postawę i poetycki światopogląd"2. Badacz podkreśla jednak, że w twórczości Miłosza mamy do czynienia z dwojakim

1 Z. Herbert Poeta sensu. Rozmawia Marek Oramus, w: Herbert nieznany. Rozmowy, zeb. i oprac. do druku H. Citko, Fundacja Zeszytów Literackich, Warszawa 2008, s. 103.

2 A. Fiut Romans z naturq, w: tegoż Moment wieczny. Poezja Czesława Miłosza, Wydawnictwo Literackie, Kraków 1998, s. 59.

\section{Magdalena}

Śniedziewska - po-

lonistka i italianistka, adiunkt w Pracowni

Poetyki Historycznej

IBL PAN. Autorka

książek Wierność

rzeczywistości.

Zbigniew Herbert

o postawie wobec

świata i problemach

jego reprezentacji

(2013) oraz Siedemnastowieczne malarstwo holenderskie $w$ literaturze polskiej po 1918.magda.przyb@ interia.pl 
pojęciem natury: idylliczna wizja „zaczarowanego" świata zostaje bowiem przełamana za sprawą "odczarowanego" obrazu rzeczywistości, w której cykliczność pór roku postrzegana jest jako monotonny, bezduszny mechanizm, zaś człowiek przestaje być częścią natury, tylko chłodnym, zdystansowanym obserwatorem jej praw ${ }^{3}$. Agata Stankowska, interpretując Ziemię Ulro, dowodzi, że u Miłosza mamy do czynienia ze swoistą dialektyką, rozdarciem „między determinizmem Natury jako całości i wolnością istnień poszczególnych"4.

O podziale na rajski świat dzieciństwa i rzeczywistość „podporządkowaną prawu rozumnej konieczności" pisze Marek Zaleski, zwracając uwagę na to, że ten rajski ogród, do którego Miłosz pragnie powrócić za sprawą Doliny Issy, jest rajem „wątpliwym, skażonym"5. Świadoma tego zastrzeżenia, spróbuję przyjrzeć się bliżej szczególnym przedstawicielom świata natury, ptakom, które w twórczości Miłosza zajmują niezwykle istotne miejsce.

W Dolinie Issy Tomasz, alter ego młodego Miłosza, daje się poznać jako miłośnik ptaków, jako ktoś wtajemniczony, wybrany, mający dostęp do, zdawałoby się, zrodzonego w dziecięcej wyobraźni, ale jednocześnie realnego, leśnego państwa ${ }^{6}$ :

Zmierzch tutaj, w tej rozmaitości, co wyłania się z obu stron drogi, inny niż w Giniu, odzywał się mnóstwem głosów z chaszczy i podmokłych łąk. Buczenia, kwaknięcia, żaby czy dzikie kaczki, albo inne ptaki. Lelki trzepały się skośnym lotem przed nimi. Tomasza przenikał nabożny podziw dla tego wrzenia w ciemności, dla tylu istot, których zwyczaje i sprawy, zakryte, wzywały, żeby poznawać i śledzić. Głupio, że ludzie wszędzie pourządzali pola. Kiedy wjeżdża się między pola, kończy się natychmiast cała piękność. Gdyby od niego to zależało, zabroniłby orać,

3 Zob. tamże, s. 6o-61.

4 A. Stankowska „Żeby nie widzieć oczu zapatrzonych w nic". O twórczości Czesława Miłosza, Wydawnictwo Naukowe UAM, Poznań 2013, S. 15.

5 M. Zaleski Zamiast. O twórczości Czesława Miłosza, Wydawnictwo Literackie, Kraków 2005, S. 29.

6 Miłosz być może nawiązuje w ten sposób do, znanej mu, powieści M. Rodziewiczówny Lato leśnych ludzi z 1920 roku. Na temat lasu jako inspiracji i jednego z istotnych motywów literackich Miłosza zob. A. Szawerna-Dyrszka Leśne tropy Miłosza, "Postscriptum Polonistyczne” $2011 \mathrm{nr} 7$, s. $53-62$. 
niechby wszędzie rosły lasy, a w nich biegały zwierzęta. Tak rozmyślał, i postanawiał, że jak dorośnie, założy takie państwo, które całe będzie lasem, ludzi się tam nie będzie wpuszczać, chyba tylko niektórych. $\mathrm{Na}$ przykład jak kto? Na przykład takich jak pan Romuald. (DI, 131) ${ }^{7}$

Miłosz słucha i patrzy albo lepiej rzec - nasłuchuje i wypatruje. Żądny jest bezpośredniego, jak najbliższego kontaktu z ptakami, a dodatkowo, planując leśne państwo, staje się orędownikiem po schillerowsku pojmowanej naiwności ${ }^{8}$, rozumianej jako chęć obcowania ze światem nieskażonym przez cywilizację. Daje w ten sposób wyraz wiary w mityczną przestrzeń, będącą kwintesencją tego, co naturalne, dzikie, samoistne. Literackim pierwowzorem leśnego państwa, które w swojej dzikości broni się przed „ludzką ręką", jest oczywiście Mickiewiczowski matecznik z Pana Tadeusza9 :

7 Wszystkie cytaty wg wydania: Cz. Miłosz Dolina Issy, Wydawnictwo Literackie, Kraków 1981. Lokalizacja przytoczeń bezpośrednio w tekście (skrót DI i nr strony).

8 Schiller definiuje naiwność jako kwintesencję naturalności, jako odwrotność wszelkich wytworów ludzkiej kultury. „W takim rozumieniu natura nie oznacza dla nas nic innego jak istnienie spontaniczne, trwanie rzeczy dzięki nim samym, egzystencję na mocy praw własnych i niezmiennych". "Naiwność - podkreśla Schiller - jest to dziecięcość występująca tam, gdzie się jej już nie oczekuje, i dlatego nie można jej przypisywać faktycznemu dziecięctwu w ścisłym tego słowa znaczeniu". F. Schiller O poezji naiwnej i sentymentalnej, w: Dzieła wybrane, t. 1, wyb., wstęp i oprac. S.H. Kaszyński, Wydawnictwo Poznańskie, Poznań 2006, s. 237, 240.

9 Miłosz, wspominając w rozmowie z A. Fiutem pierwszą lekturę Pana Tadeusza, zwraca uwagę na to, że nie interesowało go wówczas poetyckie rzemiosło Mickiewicza, stawiał bowiem pytanie o wierność opisów litewskiej przyrody: „Kiedy mówimy o literaturze, muszę Panu powiedzieć o moim pierwszym zetknięciu z Panem Tadeuszem. Było ono pełne pretensji do Mickiewicza, ponieważ ja wtedy kiedy się to stało, nie byłem nastrojony literacko, tylko byłem nastrojony przyrodniczo. Wobec tego odczułem, że coś nie jest w porządku. Mianowicie, że przyroda, której chciałem się poświęcić - życie naturalisty - że przyroda tutaj posłużyła za ornament, czy też element budowy dzieła literackiego. Albo jest przyroda, albo jest rzetelność zupełna w stosunku do przyrody, albo jest jakaś tam literatura. Ale żeby tak przekształcić przyrodę dla literatury - to jakoś nieładnie. To jest pierwsza pretensja. Nie sformułowana, ale wyczuta tak, jak mam wrażenie, teraz ja to wyczuwam. Druga pretensja jeszcze dziwniejsza. Mianowicie, jaką właściwie on przyrodę opisuje? To coś niezupełnie naszego! Dlatego, że we mnie było niesłychanie silne poczucie ekskluzywizmu, jakiegoś patriotyzmu lokalnego, w sensie krajobrazów, roślinności, drzew". Czesława Miłosza autoportret przekorny, rozm. przepr. A. Fiut, Wydawnictwo Literackie, Kraków 1988, s. 150-151. O Miłoszu i Mickiewiczu pisano niejednokrotnie. Na ten temat zob. M. Wyka Jak Miłosz czyta Mickiewicza, w: Poznawanie Miłosza 2, cz. 2, red. A. Fiut, Wydawnictwo Literackie, Kraków 2001, s. 92-101; L. Banowska Miłosz i Mickiewicz. Poezja wobec tradycji, Wydawnictwo Naukowe UAM, Poznań 2005. 
A za tą mgłą na koniec (jak wieść gminna głosi)

Ciągnie się bardzo piękna, żyzna okolica:

Główna królestwa zwierząt i roślin stolica.

W niej są złożone wszystkich drzew i ziół nasiona,

Z których się rozrastają na świat ich plemiona;

W niej, jak w arce Noego, z wszelkich zwierząt rodu

Jedna przynajmniej para chowa się dla płodu. ${ }^{10}$

W Panu Tadeuszu ta idylliczna wizja zostaje naruszona za sprawą „tradycyjnego" litewskiego polowania:

I znowu cichość w dole. Dzięcioł na jedlinie

Stuka z lekka i dalej odlatuje, ginie,

Schował się, ale dziobem nie przestaje pukać,

Jak dziecko, gdy schowane woła, by go szukać.

Bliżej siedzi wiewiórka, orzech w łapkach trzyma,

Gryzie go; zawiesiła kitkę nad oczyma,

Jak piórko nad szyszakiem u kirasyjera;

Chociaż tak osłoniona, dokoła spoziera;

Dostrzegłszy gościa, skacze gajów tanecznica

$\mathrm{Z}$ drzew na drzewa, miga się jako błyskawica;

Na koniec w niewidzialny otwor pnia przepada,

Jak wracająca w drzewo rodzime dryjada.

Znowu cicho.

Wtem gałąź wstrzęsła się trącona

I pomiędzy jarzębin rozsunione grona

Kraśniejsze od jarzębin zajaśniały lica:

To jagód lub orzechów zbieraczka, dziewica;

W krobeczce z prostej kory podaje zebrane

Bruśnice świeże jako jej usta rumiane;

Obok młodzieniec idzie, leszczynę nagina,

Chwyta w lot migające orzechy dziewczyna.

Wtem usłyszeli odgłos rogów i psów granie:

Zgadują, że się ku nim zbliża polowanie,

10 A. Mickiewicz Pan Tadeusz, oprac. S. Pigoń, Ossolineum, Wrocław 1996, s. 215. 
I pomiędzy gałęzi gęstwę, pełni trwogi,

Zniknęli nagle z oczu jako lesne bogi."

Z podobną sytuacją mamy do czynienia również u Miłosza. Tomasz nieświadomie dokonuje aktu agresji, pozwalając panu Romualdowi, myśliwemu, wkroczyć do królestwa lasu. Ulega wówczas - o czym się niebawem przekonamy - podszeptom „ja”.

Kiedy bierzemy do ręki Dolinę Issy, już od pierwszej strony dzielimy z Miłoszem zachwyt światem przyrody, słuchamy charakterystycznego języka litewskiej awifauny, poznajemy, zależne od rytmu pór roku, zwyczaje ptactwa nazywanego po imieniu z niezwykłą precyzją:

I zawsze w pewnej chwili jest z pagórka widok na niebieską taflę jeziora z białą, ledwo dostrzegalną plamką perkoza, ze sznurem kaczek ciągnących nad trzcinami. Na bagnach lęgną się tutaj masy błotnego ptactwa, na wiosnę w bladym tutejszym niebie trwa wracający seriami warkot, wa-wa-wa bekasów - taki dźwięk wydaje powietrze w ich sterach z piór, kiedy odprawiają swoje monotonne akrobacje oznaczające miłość. Ten wątły warkot i bełkot cietrzewi, jakby gdzieś daleko gotował się horyzont i kumkanie tysięcy żab na łąkach (ich liczba decyduje o liczbie bocianów, mających swoje gniazda na dachach chat i stodół) są tutaj głosami tej pory, kiedy po gwałtownym topnieniu śniegów kwitnie kaczeniec i wilcze łyko - drobne różowoliliowe kwiatki na krzakach jeszcze bez liści. Dwie pory roku są temu krajowi właściwe, jakby dla nich był stworzony: wiosna i jesień - długa, najczęściej pogodna, pełna zapachów moknącego lnu, stukania międlic, biegnących z daleka ech. Gęsi ogarnia wtedy niepokój, zrywają się nieporadnie chcąc wzbić się za dzikimi, które nawołują z wysoka; zdarza się, że ktoś przynosi do domu bociana ze złamanym skrzydłem: to ten, co uratował się od śmierci, jaką towarzyszowi niezdolnemu lecieć w podróż nad Nil wymierzają dziobami strażnicy prawa: opowiada się, że tam i tam wilk porwał komuś wieprzaka; z lasów słychać muzykę psów gończych: sopran, bas i baryton szczekają w biegu, goniąc za zwierzyną i po modulacji poznaje się, czy idą śladem zająca czy sarny. (DI, 5-6)

Widzimy, z jaką lekkością Miłosz otwiera i oswaja przestrzeń przyrody, moglibyśmy nawet powtórzyć za Herbertem, że jest „cały wydany naturze”. 
Jednak w końcowym fragmencie tego przytoczenia, na ten cyklicznie odradzający się świat pada cień, czego pisarz - jak sądzę - nie jest świadomy. "Muzyka psów gończych” (będąca aluzją do Mickiewiczowskiego „psów grania") zdaje się tu stanowić naturalny element wiosennych rytuałów budzącej się do życia natury. Słyszymy zatem - dla nas niepokojące - echa Mickiewiczowskich "tradycyjnych" polowań z Pana Tadeusza. Z jednej strony Miłosz niejednokrotnie daje w Dolinie Issy wyraz niezwykłej świadomości bycia częścią kreowanego przez siebie „państwa”, z drugiej jednak sprzeniewierza się jego odwiecznym regułom, kiedy - ulegając podszeptom rozrastającego się „ja” - bierze do ręki myśliwską broń i niszczy bezinteresowną więź, która łączyła go z Królestwem Lasu. Choć tu należałoby zadać pytanie, czy ta bezinteresowna więź w ogóle istniała... Dobitnie brzmią w tym kontekście słowa Bernda Heinricha, który z pełnym przekonaniem stwierdza: „Jestem [...] przeświadczony, że nasza pomyślność zależy nie tyle od struktury społecznej i określającej ją polityki, ile od zdolności dotrzymania umowy z przyrodą, poczucia, że jesteśmy częścią porządku naturalnego i że umiemy się w nim utrzymać"12.

W moim odczuciu stosunek Miłosza do zwierząt (a zwłaszcza ptaków), dający się zrekonstruować na podstawie lektury Doliny Issy, jest paradoksalny. Poeta staje się orędownikiem dwóch, niedających się pogodzić, stanowisk. Spójrzmy na fragment, w którym Tomasz po raz pierwszy sprzeniewierza się bezinteresownej, po schillerowsku naiwnej miłości do ptasiego świata:

Pierwszy raz Tomasz asystował podstępom, jakich człowiek używa wobec zwierzyny, kiedy przyjechał do Borkun na kilka dni pomagać zbierać grzyby [...]. Pan Romulad łęk kosza przewiesił przez ramię, przytrzymywał ręką rzemień fuzji, na sznurku w kieszonce trencza miał kościany wabik, który, jak powiedział, może się przydać. Wabiki wyrabia się ze skrzydła sowy, czasem z kości zajęczej, ale wtedy ton ich nie jest tak czysty. Na tym wabiku naśladuje się trel jarząbka, a to dlatego, że inaczej nie dadzą się wypatrzeć, przy każdym niebezpieczeństwie przytulają się do pnia tak, że nie odróżni się ich od kory. Na dany znak Tomasz znieruchomiał z nożykiem przyłożonym do grzyba, w ciszy sypiącego się igliwia odezwało się drżące gwizdanie. Powolutku wsunęli się w gęstwinę, w półmrok. Pan Romuald przyłożył do ust wabik. Dmuchał delikatnie i przebierał palcem

12 B. Heinrich Chrapiący ptak. Rodzinna podróż przez stulecie biologii, przeł. M. Szczubiałka, Czarne, Wołowiec 2016, s. 40. 
po dziurkach. Cisza. Serce Tomaszowi waliło tak głośno, że bał się, żeby nie było tego słychać. Nagle odpowiedział jarząbek, i znów, bliżej. Furkot i przed nimi, na gałęzi świerku, zobaczył w rudej ciemności cień, który kręcił głową na wszystkie strony, szukając towarzysza. Podrzut ramienia tak szybki, że echo strzału rozległo się z nim równocześnie, a kiedy rozwiał się dym (Romuald używał dymnego, nie bezdymnego prochu), jarząbek leżał nieruchomo pod drzewem, ledwo do odróżnienia od ściółki zeschłych igieł. (DI 136-137)

To pierwsze wtajemniczenie zrodzi późniejszą fascynację myślistwem. Wiedzę na temat wabienia jarząbków Miłosz zaczerpnął najprawdopodobniej z książki Włodzimierza Korsaka Rok myśliwego. Rzecz dla myśliwych i miłośników przyrody z 1922 roku. W rozdziale zatytułowanym Wabienie jarząbów (i we wcześniejszym Naganki na jarzabki) zostały szczegółowo opisane sposoby polowania na te ptaki ${ }^{13}$. Rozpoczynając opis wabienia jarząbka, Miłosz używa słowa „podstęp", które w najlepszy sposób oddaje nieczystość postępowania Romualda i jego asystenta, Tomasza. Ptak został oszukany - szukał towarzysza, a napotkał śmierć.

Wraz z wkroczeniem w świat łowiecki perspektywa, z jakiej Tomasz zaczyna postrzegać dzikie zwierzęta, niemal całkowicie się zmienia. Bezinteresowność wiedzy na temat ptasich zwyczajów i zachowań ustępuje miejsca interesowności. Ten proces można obserwować na wielu płaszczyznach. Wiemy, że na kartach Doliny Issy Miłosz z niezwykłym wyczuciem stara się naśladować głosy ptaków (o ile w słowach można oddać lub choćby zasugerować ten śpiew). Etycznie wątpliwą kulminacją tych zdolności jest wabienie

13 W. Korsak Rok myśliwego. Rzecz dla myśliwych i miłośników przyrody, z ilustracjami Autora, Artemix, Warszawa 2006, s. 122-124. W książce zachowana jest oryginalna pisownia i interpunkcja z poznańskiego wydania z 1922 roku. Korsak pisze o wabikach "kościanych”, podkreślając, że „najlepsze wyrabiane są z kości skrzydłowej kruka lub sowy". Samo zaś polowanie wygląda tak: "Myśliwy, przyszedłszy w miejsca, gdzie się jarząbki trzymają, posuwa się zwolna, przystając od czasu do czasu i wabiąc. Słucha też pilnie, czy gdzie jarząbek nie odpowie. [...] Gdy ptak odpowiada, wab powtarzać trzeba co 10-60 sekund, zależnie od sposobu tej odpowiedzi; nieraz opóźnienie wabia na bardzo gwałtowne gwizdanie jarząbka pobudza go do zbliżenia się. Jeżeli się wabi umiejętnie, to po paru odpowiedziach jarząbek zaczyna się zbliżać, biegnąc i gwiżdżąc, albo przelatując z drzewa na drzewo z furkotem, podobnym do oddalonego grzmotu. Myśliwy powinien się wówczas ukryć za pniem drzewa lub za krzakiem i - zwłaszcza jeżeli jarząbek biegnie, pilne dawać baczenie, by ptak zawcześnie niebezpieczeństwa nie spostrzegł. [...] Strzał bywa łatwy, gdyż bądź to do biegnącego, bądź też do siedzącego ptaka, rzadko zaś w lot [...]". Tamże, s. 123. 
przez Tomasza młodych jastrzębi, które potem stara się upolować (dwukrotnie strzela celnie). Pewien swych naśladowczych zdolności tłumaczy: „«Pii-ii» - przenikliwy krzyk musi wychodzić ze ściśniętego gardła i tu tkwi trudność, bo powtórzyć ileś razy, a odczuwa się ból" (DI, 223). Ta próba przeniknięcia do świata jastrzębich obyczajów w rzeczywistości nie jest prawdziwym zbliżeniem się do natury. Szczególnie dobitnie pokazuje to kolejny fragment, w którym Tomasz zdaje emocjonującą relację z fałszywego - jak sądzę - utożsamienia:

Zaryzykować i wabić, jedyny sposób. Zapominając, że jest sobą, przybrał duszę jastrzębia, tak starał się, żeby dobrze mu wypadło. „Pii-ii”. I tamten, podniecony, rzucił odzew. Załopotał, to wystarczyło, żeby Tomasz go wypatrzył. Celował prawie na oślep, raczej zgadywał, niż widział myszatą plamę w czerni. Po strzale ptak zerwał się, zwinął się i spadał tłukąc się, usiłując się zatrzymać. Tomasz skoczył ku niemu, witki siekły go po twarzy. Już drugi, zabił drugiego - śpiewało w nim. Zastał go leżącego na wznak, jeszcze żywego, szpony sterczały obronnie. Zamiast towarzysza czy matki, których zaproszenie tak wyraźnie do niego się kierowało, olbrzymia istota pochylała się nad nim, porażonym niemocą. Tomasz oczywiście czerpał usprawiedliwienie swego postępku w tym, że drapieżnik karmił się mięsem i krwią rozdzieranych przez siebie gołębi i kurczaków ${ }^{14}$. Stuknął go więc kolbą w głowę i złote oczy przesłoniły się od dołu powieką. Mięso po zdjęciu skóry oddane zostanie Lutni, a wypchana skóra zachowa przez pewien czas pozór tej właśnie, a nie innej osoby, zanim nie zalęgną się w nim mole.

14 O okrutnym drapieżnictwie jastrzębia pisał (z pewną przesadą) pod koniec XIX wieku polski przyrodnik, Bohdan Dyakowski w znanej Miłoszowi książce Nasz las i jego mieszkańcy: „Oto na starym wysokim dębie, co niedawno dopiero okrył się liśćmi, w rozwidleniu dwu okazałych konarów, niezbyt daleko od wierzchołka, sterczy spore i dość płaskie gniazdo, sklecone z grubszych gałęzi, wysłane obficie drobnymi gałązeczkami sośniny. To siedziba ja s $\operatorname{tr}$ z ę b i a, jednego z najgroźniejszych rozbójników leśnych, postrachu wszystkich ptaków i nie ptaków. Tu wysiaduje i hoduje dzieci, stąd wyrusza na łowy, tu młodym swym znosi na pokarm nieszczęsne ofiary. Poluje na nie zajadle, bez przerw prawie i wytchnienia. Aktywny jest od rana do nocy, nawet w samo południe, kiedy inne ptaki drapieżne oddają się wypoczynkowi. Urodzony to drapieżca, żądny krwi i mordu, wiecznie głodny, wiecznie poszukujący nowych ofiar, aby zaspokoić swój nienasycony apetyt. Ale nawet wtedy, gdy się już naje do woli, gdy więcej przełknąć nie może, jeszcze poluje dalej, jeszcze goni, zabija i rozszarpuje dla samej przyjemności zabijania, dla samej wprawy w łowach". B. Dyakowski Nasz las i jego mieszkańcy, z fot. W. Puchalskiego, Zysk i S-ka, Poznań 2016, s. 104. 
Jeżeli Tomasza nawiedzały skrupuły (co się zdarzało), tłumaczył sobie, że stworzenie, które zabija, i tak umrze, więc chyba wszystko jedno, czy trochę wcześniej czy później. Jakoś że zwierzęta chcą żyć, nie było całkowicie wystarczające, bo on przecie miał cel - zwyciężenia, wypchania, i ten cel wydawał się ważniejszy. (DI, 223-224)

Tomasz, samousprawiedliwiając się, nie bierze pod uwagę tego, że nie jest poszukującym jedzenia drapieżnikiem, że nie zabija, by zaspokoić głód. Ten fragment chciałabym zestawić z uwagami Helen Macdonald, która w przejmujący sposób opisywała swój sokolniczy epizod z samicą jastrzębia o imieniu Mabel:

Mabel nie jest człowiekiem. Ze wszystkich nauk, jakie wyniosłam z tych spędzonych z nią miesięcy, ta jest najważniejsza: istnieje świat rzeczy skał i drzew, kamieni i trawy oraz wszystkiego, co pełza, biega i fruwa. Są rzeczami samymi w sobie, ale my, żeby je zrozumieć, nadajemy im znaczenia potwierdzające nasze widzenie świata. Przebywając z Mabel, nauczyłam się, jak czuć się bardziej człowiekiem, kiedy poznało się, choćby w wyobraźni, co to znaczy nim nie być. Nauczyłam się też, jak niebezpieczne jest mylenie dzikości, którą czemuś przypisujemy z dzikością będącą prawdziwą cechą. Jastrzębie to wcielona śmierć, krew i horror, ale nie usprawiedliwiają potworności. Ich nieludzkość należy cenić, bo to, co robią, nie ma nic wspólnego z nami. ${ }^{15}$

Tomasz nie jest empatyczny, mimo że wydaje mu się, iż stapia się z duszą jastrzębia. Ważniejszy dla niego nie jest jednak jastrząb jako dziki przedstawiciel świata zwierząt, ale jako myśliwskie trofeum. Liczy się nie „on”, jastrząb, tylko „ja”, zwycięzca. Widzimy zatem, że reguły tego leśnego państwa są arkadyjskie tylko z pozoru. Już w samym słowie „państwo” czy „królestwo” kryje się założenie systemowości, czujemy ingerencję ludzkiej ręki i ludzkich praw. Tak samo, dodajmy, jak w Panu Tadeuszu, w którym Mickiewicz nazywa matecznik "główną królestwa zwierząt i roślin stolicą" ${ }^{\text {, }}$, zaś poszczególne

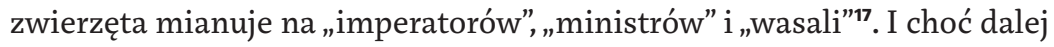

H. Macdonald / jak jastrząb, przeł. H. Jankowska, Czarne, Wołowiec 2016, s. 322-323.

16 A. Mickiewicz Pan Tadeusz, s. 215.

17 Tamże, s. 216. 
czytamy, że mieszkańcy matecznika „jeszcze cywilizacją ludzką nie popsuci"18, to jednak coraz trudniej uwierzyć nam w pojednawcze gesty "gospodarza poematu"19 , jak zwykł o narratorze Pana Tadeusza pisać Kazimierz Wyka. Okazuje się bowiem, że ani Miłosz, ani Mickiewicz nie potrafią bądź nie chcą wykroczyć poza horyzont poznawczy, jaki wyznacza antropocentryczny punkt widzenia. Dlatego przestrzeń, z której człowiek jest wyłączony, usiłują zawłaszczyć dzięki językowi - nazywając, nadając funkcje, określając w zgodzie z ludzkim doświadczeniem. Mimo tego wysiłku świat zwierząt pozostaje nieuchwytny, jakby poza słowem. Lepiej zdawał sobie chyba z tego sprawę Mickiewicz, który odgrodził matecznik od świata ludzi trzema granicami, niemożliwymi do sforsowania przez człowieka: „Szczęściem, człowiek nie zbłądzi do tego ostępu, / Bo Trud i Trwoga, i Śmierć bronią mu przystępu"20. Miłosz zdaje się w tym przypadku dużo bardziej liberalny - pozwala bowiem Tomaszowi wyznaczyć ścisły podział na „dorosłych”, którzy sprzeniewierzyli się dzikiej naturze, i „wybranych", mających dostęp do matecznika. Jednak poczynione przez bohatera Doliny Issy dystynkcje są u samych już podstaw niewiarygodne, po prostu - fałszywe:

Romuald zasługiwałby na to, żeby wpuścić go do Królestwa, do którego wstęp zwyczajnym ludziom byłby wzbroniony. Bo przejmował się obecnością zwierzyny, muskuł latał mu w policzku, zmieniał się cały w czujność i na pewno nic poza tym na świecie wtedy go nie obchodziło. Co innego jego gospodyni Barbarka - ta należała do dorosłych, szkoda, taka ładna i wyglądająca prawie dziecinnie. Że ludzie żyją odnosząc się obojętnie do tego, co najważniejsze, powinno nas zasmucać - nie wiadomo, czym właściwie wypełniają swoje życie. (DI, s. 137)

Dotykamy tu wraz z Miłoszem problemu, który w tak przejmujący i wiarygodny sposób rozważał Zenon Kruczyński, autor książki Farba znaczy krew i były myśliwy. Czy myśliwi są prawdziwymi miłośnikami przyrody, znawcami jej praw i tajemnic? Czy sumienie myśliwego może być spokojne, skoro istnieje „etyka myśliwska”, oparta na kilku - z pozoru szczytnych - założeniach? „Etyka myśliwska - stawia mocną tezę Kruczyński - jak każda inna

Tamże, s. 217.

K. Wyka „Pan Tadeusz". Studia o poemacie, PIW, Warszawa 1963, s. 23. 
«etyka zabijania», ustanowiona jest na zdradliwym gruncie. Zręcznie omija najwyższą wartość: życie"21.

Wiemy już, że Miłosz czytał podręcznik Włodzimierza Korsaka Rok myśliwego. Rzecz dla myśliwych i miłośników przyrody z 1922 roku i inspirował się̨22 nim, pisząc Dolinę Issy. Później w bezpośredni sposób nawiązał do książki Korsaka, nadając swojemu tomowi esejów tytuł Rok myśliwego. Już podtytuł pracy Korsaka, Rzecz dla myśliwych i miłośników przyrody, budzi niepokój, każe myśleć o paradoksie zawartym w zestawieniu „myśliwy” i „miłośnik przyrody”. Te określenia, zarówno dla Korsaka, jak i dla Miłosza, miały charakter synonimiczny. Spójrzmy na wstępny fragment rozważań Korsaka: „[...] myśliwstwo właściwe zaczyna się dopiero tam, gdzie główną pobudką nie jest chęć zarobku, ale szukanie wrażeń estetycznych i emocyj, jednem słowem motywy natury moralnej. Jako takie ma myśliwstwo nadzwyczaj dodatnie znaczenie dla człowieka, zbliżając go na powrót do przyrody, od której go kultura tak zabójczo oddala"23. W dalszych refleksjach znajdujemy uwagi w podobnym tonie:

Pożądanem więc jest, by jaknajwiększa ilość młodzieży garnęła się do tego pożytecznego, pięknego i szlachetnego kunsztu, wyrabiając w sobie należyte pojęcie o istocie myśliwstwa, polegającej nie na zabiciu największej ilości zwierzyny i prześcignięciu w tem swych współtowarzyszy, ale na umiłowaniu dzikiej przyrody, badaniu jej wszystkich tajemnych przejawów i zżyciu się kompletnem z jej bytem i treścią. Wewnętrzne życie puszczy, tak piękne, bujne i szerokie, a tak mało dostępne dla ludzi, obracających się w ciasnem kółku swych marnych spraw i zarażonych od dziecieństwa przez zgniłe tchnienie miejskiego zepsucia, leży jak otwarta księga przed temi, którzy pragną w niej czytać i siły żywotne czerpać. ${ }^{44}$

Z. Kruczyński Farba znaczy krew, Czarne, Wołowiec 2017, s. 106.

W 1982 roku, w rozmowie z A. Fiutem, Miłosz wyznaje: „istniała cała literatura myśliwska skoncentrowana na Litwie. Głównym pisarzem był w tym zakresie Włodzimierz Korsak, który pochodził w Witebszczyzny. No i oczywiście gloryfikował przyrodę tego, co się w szerokim słowa znaczeniu nazywa Litwą. Więc na pewno te rzeczy oddziaływały bardzo silnie. Taka książka Włodzimierza Korsaka Rok myśliwego. Ostatecznie to była książka nie o Polsce, tylko właściwie o porach roku, o zwierzynie tak zwanej Litwy historycznej. Te rzeczy wpływały. Czesława Miłosza autoportret przekorny, s. 150. 
Wzniosłe ideały myśliwskiej „etyki” (Korsak niejednokrotnie powołuje się na nią) bardzo szybko zostają zdyskredytowane przez samego autora, który radzi, jak polować na kaczki: „Inna rzecz się ma z polowaniem na rzece. Tam, jadąc łódką, a zwłaszcza mając jeszcze po obu brzegach naganiaczy, można często nastrzelać się do woli i obfite trofea zdobyć" ${ }^{25}$. To jedno z wielu miejsc w podręczniku łowieckim Korsaka, w którym zostaje obnażona nieprzystawalność z pozoru wzniosłej, lecz bardzo mglistej teorii i praktyki, a lepiej rzec - myśliwskiego zaślepienia. Z podobnym problemem mamy do czynienia także u Miłosza.

Przykłady zawoalowanego myśliwskiego okrucieństwa z Doliny Issy można by mnożyć. Chciałabym jednak przywołać jeden epizod, który w najbardziej przejmujący sposób obrazuje paradoksalność myślenia Tomasza. Chodzi mi o opis polowania na głuszca: „I ten dźwięk. Tomasz zrozumiał, dlaczego tak ceni się to polowanie. Żadnej innej pieśni równie ściśle wyrażającej dzikość wiosny nie umiałaby wynaleźć natura. Nie melodia, nie wdzięczny trel - nic więcej niż stukanie bębna, który przyspiesza rytm, tętna walą w skroniach, aż pieśń głuszca i bęben tłukący się w pieśni zlewają się w jedno. Bez podobieństwa do głosu żadnego innego ptaka, nie poddający się opisowi dźwięk" (DI, 175-176). Pieśnią głuszca zachwycał się również Korsak: „Tam, w pobliżu brzegu suchego lasu lub na wyspie porosłej sosną i świerkami, rozlega się na wiosnę czarowna pieśń króla puszczy - głuszca [... $]^{\text {26 }}$. Rozdział $Z$ wyżłem na głuszce rozpoczynał od słów:

Ten król naszej skrzydlatej zwierzyny, tajemniczy śpiewak nocy, nieczęsty jest niestety na ziemiach polskich; mało jest zakątków, któreby się poszczycić mogły wielką ich ilością. Na przeważnej przestrzeni Litwy i Białej Rusi rzadki jest i coraz rzadszy się staje, gnieciony przez postęp kultury, a raczej wprost przez przenikanie ludzi wgłąb wielkich lasów, tej prasiedziby olbrzymiego ptaka. ${ }^{27}$

Celny strzał Romualda nie jest dla Tomasza traumą, wręcz przeciwnie "Jest w nim szczęśliwość i dziękczynienie Bogu" (DI, 177). Najbardziej niewiarygodna jest jednak refleksja podsumowująca to nadzwyczajne polowanie:

25 Tamże, s. 25.
26 Tamże, s. 45.
27 Tamże, s. 57. 
„Uderzył piorun i zabił. A on, Tomasz, przebywał z piorunem, z drugiej strony spotkali się tak, jak mogli się spotkać i trochę żal, że nigdy inaczej, tylko tak. Właściwie tęsknił do porozumienia z różnymi żyjącymi istotami takiego, jakiego nie ma. Czemu ta przegroda i czemu, jeśli się kocha naturę, trzeba zostać myśliwym" (DI, 177)

Miłosz konstruuje swoją opowieść w taki sposób, by dać do zrozumienia, że poznanie obyczajów godowych głuszca jest możliwe tylko z perspektywy osoby, która zdobywa wiedzę na temat tego ptaka jedynie po to, by móc go upolować. Logika myślenia Tomasza opiera się na błędnej przesłance. Końcowe pytanie jest z gruntu fałszywe. Przecież, jeśli naprawdę kocha się przyrodę, nie wolno zostać myśliwym... Jego zdaniem, istnieją niedostępne rejony lasu, w których można podziwiać niespotykane nigdzie indziej ptaki, a te miejsca odwiedzane są wyłącznie przez „wtajemniczonych”, czyli myśliwych - prawdziwych znawców leśnych sekretów, prawdziwych mieszkańców Królestwa $\mathrm{Lasu}^{28}$. Tomasz zupełnie nie bierze pod uwagę tego, że wiedza zdobywana przez myśliwych jest interesowna. Fascynujący go Romuald drobiazgowo potrafi opisać rytuały godowe głuszca, ale jest bezradny wobec napotkanych przypadkiem małych ptaszków, niegodnych - chciałoby się rzec - myśliwskiej lufy:

Wstał i zadzierał głowę, ale świerk, skąd sypały się łuski szyszek, był ogromny, tam wysoko małe ptaszki trzepotały się, przemknęło skrzydło prześwietlone blaskiem słońca, jednak prócz trzepotu nic nie mógł rozróżnić. Obchodził drzewo naokoło, bez skutku. A korciło go, bo nie znał ich nazwy, z tak daleka nie poznawał i w ogóle z tymi małymi ptakami miał największy kłopot. Romuald na przykład pytany o ich gatunki machał tylko ręką: „A kto ich tam wie?” (DI 273-274)

28 W podobny sposób o myśliwskim wtajemniczeniu Miłosza pisał, powołując się na uwagi J. Błońskiego, A. Fiut, zwracając jednak uwagę na, związane z polowaniem, niebezpieczeństwo zawłaszczania, posiadania, "urzeczowienia”: „Inną drogą w głąb przyrody było dla Tomasza polowanie. Stanowi ono - jak kiedyśzauważył Jan Błoński - «symbol poznania natury. Inaczej: nie wynik poznania, ale sam akt poznawania interesuje Miłosza - przedstawia on przyrodę, nierozerwalnie złączoną z odkrywcą» (J. Błoński Dolina Issy, „Przegląd Kulturalny” 1957 nr 24). Ale i ten rodzaj poznania Natury, jakże doskonały, bo pozwalający dostrzec i naśladować rządzące nią prawa, także natrafia na nieprzekraczalną barierę. Chęć posiadania, pragnienie zatrzymania zmiennego piękna mogą być spełnione tylko za cenę urzeczowienia [...]". A. Fiut Wygnanie z raju, w: Poznawanie Miłosza. Studia i szkice o twórczości poety, red. J. Kwiatkowski, Wydawnictwo Literackie, Kraków-Wrocław 1985, s. 323. 
Casus Miłosza warto zestawić z wierszem Głuszec włoskiego noblisty, Eugenia Montalego, z tomu La bufera e altro (są to wiersze z lat 1940-1954, opublikowane w 1956 roku):

Gdzie upadasz po szybkim strzale (twój głos bulgocze, czerwonoczarny gulasz z nieba i ziemi na wolnym ogniu) ja także kulę się, płonę w rowie.

Łkanie prosi o pomoc. Rozkoszniej było żyć niż grzęznąć w tej magmie, łatwiej rozkładać się na wietrze niż tu w błocie, zeskorupiali w płomieniu.

W piersi czuję twoją ranę, pod skrzepem skrzydła, mój ciężki lot mierzy się z murem i zostanie z nas tylko kilka piór na oszronionym ostrolistnym dębie.

Bójki drapieżnych dziobów, gody, gniazda jaj marmurkowych, boskie! Teraz pączek roślin wieloletnich, jak gąsienica, migocze w ciemności, Jowisz jest pogrzebany. ${ }^{29}$

Paulina Malicka trafnie pisała o Głuszcu jako poetyckim „przykładzie [...] ludzkiego współodczuwania"30. Sądzę, że można by pójść krok dalej i rzec, że wiersz Montalego jest więcej niż empatyczny. Zwraca uwagę totalność próby utożsamienia się z cierpiącym głuszcem („W piersi czuję twoją ranę"). Strzał rodzi cierpienie, mamy do czynienia z silnym doświadczeniem bólu, z bezsilnością, słabością zarówno ptaka, jak i człowieka, z wołaniem o pomoc. Jakże to odmienne od "szczęścia” $i$,dziękczynienia” Tomasza, młodego adepta

29 E. Montale Il gallo cedrone, w: tegoż, Tutte le poesie, a cura di G. Zampa, Mondadori, Milano 1990, s. 261.

30 P. Malicka W poetyckim zoo Eugenia Montalego, w: Człowiek w relacji do zwierzq̨t, roślin i maszyn w kulturze, t. 2: Od humanizmu do posthumanizmu, red. J. Tymieniecka-Suchanek, Wydawnictwo UŚ, Katowice 2014, s. 114. 
sztuki myśliwskiej, który poczuł swoją siłę. Sądzę, że tego właśnie zabrakło u Miłosza: pełnego przeżycia ptasiego cierpienia.

Fascynacja myślistwem nie jest jedyną formą odejścia od, nieskażonego cywilizacją, świata natury. Okazuje się, że Tomasz z jednej strony ceni sobie kontakt z dzikim ptactwem Litwy, z drugiej jednak pociąga go potrzeba zdobycia systematycznej wiedzy na jego temat, zawładnięcia nim w sposób intelektualny. W Dolinie Issy Miłosz pokazuje, że jego miłość do ptaków i wiedza o nich ma swoje źródło w bezpośrednim obcowaniu z nimi w naturalnym środowisku, ale odkrywa przed czytelnikami również efekty regularnej pracy badawczej chłopca, który z przyjemnością oddaje się zadaniu klasyfikacji ptasich gatunków. Taką funkcję pełni jego - magiczny niemal - zeszyt „Ptaki”:

Ów zeszyt dowodził zdolności Tomasza do skupienia uwagi na tym, co go pasjonowało. Trud się opłacał, bo nazwać i zamknąć ptaka w piśmie to prawie to samo, co mieć go na zawsze. Nieskończona ilość barw, odcieni, świstów, gwizdów, trzepotów - przewracając karty miał je tutaj przed sobą, działał i porządkował jakoś nadmiar tego, co jest. W ptakach wszystko właściwie skłania do niepokoju: dobrze, one są, ale czy można tylko to stwierdzić i dalej nic? Światło mieni się na ich piórach, kiedy leca, od żółtego ciepłego wnętrza dziobów, które młode otwierają w gnieździe utajonym w gąszczu, przenika nas prąd miłosnej wspólnoty. I ludzie uważają ptaki za drobny szczegół, taką sobie ruchomą ozdobę, ledwo raczą ją zauważyć - kiedy powinni by byli całe życie poświęcić temu jednemu celowi, jeżeli znaleźli się razem z podobnymi dziwami na ziemi: rozpamiętywaniu szczęścia. (DI, 152)

W tym fragmencie, kiedy mowa o nazywaniu ptaków jako ich zawłaszczaniu, mamy już pierwsze sygnały refleksji, która będzie znamionować „ptasią" poezję i eseistykę Miłosza. Wyraźnie daje się bowiem zauważyć, że w wierszach Miłosz rozważa, inny niż w Dolinie Issy, problem natury ontologicznej. W poezji rzadko podejmuje on próby charakterystyki konkretnych gatunków ptaków. Uwagi o nich pojawiają się na zasadzie olśnień (jak w wierszu Wezwanie, gdzie „[...] ścielą się doliny, / Dęby w przepychu lata stoją, leci kraska / I zimorodek zmienia rzekę w dziwo"31) czy odniesień do

31 Cz. Miłosz Wiersze wszystkie, wyd. 2 uzup., Znak, Kraków 2015, s. 633. O zimorodku jako motywie literackim pisałJ. Axer, najpierw w kontekście zachowanych fragmentów poematu Pan Tadeusz J. Słowackiego (gdzie zimorodek to "dziw lasów, tak rzadko widziany", "w stróża Anioła kolo- 
przeszłych doświadczeń (oto fragment wiersza W Szetejniach: „Wybiegłem o letnim świcie między głosy ptaków i wróciłem, a między chwilą i chwilą napisałem dzieło"32). Najczęściej jednak tematem jest szeroko rozumiana „ptaszość". W poezji dominuje wizja - powiedziałby Herbert - klasyczna. Dobrym przykładem jest napisany w 1958 roku wiersz Sroczość z tomu Król Popiel i inne wiersze (1962):

Ten sam i nie ten sam szedłem przez las dębowy

Dziwiąc się, że muza moja, Mnemozyne,

Nic nie ujęła mojemu zdziwieniu.

Skrzeczała sroka i mówiłem: sroczość,

Czymże jest sroczość? Do sroczego serca,

Do włochatego nozdrza nad dziobem i lotu

Który odnawia się kiedy obniża

Nigdy nie sięgnę a więc jej nie poznam.

Jeżeli jednak sroczość nie istnieje

To nie istnieje i moja natura.

rach, / nad zwierciadłem Przełomki, piękny i błyszczący / Jak anioł w równi złote skrzydła trzymający", w charakterystyczny sposób polujący na ryby: „ów ptak z jasnym grzbietem / Poleciał i bił w ryby dziobem jak sztyletem"), a następnie Wezwania Miłosza. Zob. .. Axer Lot zimorodka, „Przegląd Humanistyczny" 1983 nr 3, s. 75-77. Fragmenty z Pana Tadeusza Słowackiego cytuję za J. Axerem (tamże, s. 75-76). Zob. również: tegoż Dalszy lot zimorodka „Przegląd Humanistyczny” $1987 \mathrm{nr}$ 4, S. 45-49. Axer w wierszu Miłosza dopatruje się aluzji do poetyckiego opisu, który wyszedł spod pióra Słowackiego. Jednak pod koniec pracy dokonuje, w formie puenty, weryfikacji swojego odczytania niejako "u źródła”: „Otóż zdarzyło się, że w czasie «chodzonego» przyjęcia z okazji polonistycznej konferencji w Bloommington, miałem okazję i odważyłem się zapytać Miłosza o to, czy jego zimorodek jest aluzją do zimorodka Słowackiego, dodając, że to wspaniały sposób tak - jednym gestem - przemienić krajobraz „za murem więziennym” - w Litwę. Jaka aluzja, jaka Litwa - usłyszałem i zaraz: tego Słowackiego to wcale nie pamiętam, a ten pejzaż, to pejzaż znad francuskiej Dordogne, bo w tej okolicy bywałem wtedy na wakacjach i tam było mnóstwo zimorodków. «Tak to właśnie poloniści domyślają się w poezji zależności tam, gdzie ich wcale nie ma» - zakończył sentencjonalnie Miłosz z pewnym znużeniem, bo tego wieczoru zadano mu już wiele nie zawsze rozsądnych pytań i wyrażano sporo, nie zawsze sensownych przypuszczeń, co do natury jego poezji. Grom z jasnego nieba. Więc dlaczego to się tak kojarzy z Litwą? - wyjąkałem bezradnie, czując się najnędzniejszym z «wpływologów». Miłosz pocieszająco napomknął (odchodząc ku innej grupie gości), że owszem, co do zimorodków to bywało ich zawsze dużo także i na Litwie, i że w ogóle dlatego właśnie Dordogne tak mu się spodobała, że do Litwy taka podobna. I jeszcze zanim zrozumiałem głębszy sens tego wyjaśnienia, nagle oświadczył: «Wie pan, jak pomyślę - to rzeczywiście bardziej będzie Litwa»". Tamże, s. 48. 
Kto by pomyślał, że tak, po stuleciach, Wynajdę spór o uniwersalia. ${ }^{33}$

Pytanie o to, jak uchwycić, jak zdefiniować „sroczość”, początkowo rodzi pokusę poszukiwania odpowiedzi w drobnym szczególe wyglądu ptaka („do włochatego nozdrza nad dziobem") czy w charakterystycznym, falistym locie, doskonale oddanym w poetyckiej frazie (Miłosz pisze o locie, „Który odnawia się kiedy obniża"). Okazuje się jednak, że te precyzyjne rozważania na temat srok mają doprowadzić do nieprecyzyjnej, abstrakcyjnej refleksji na temat istoty wszelkich stworzeń (a więc zarówno ptaka, jak i człowieka), która jest niepoznawalna, ale może być - przekonuje poeta - przeczuta. Paradoksalnie w wystudiowanej refleksji na temat „sroczości” Miłosz wydaje się bardziej empatyczny niż w Dolinie Issy.

Podobny koncept pojawia się w Widzeniach nad Zatoka San Francisco (które po raz pierwszy ukazały się w Paryżu w 1969 roku):

O klasyfikacje! Czy tylko w umyśle czy, pomimo wszystko, też poza nim? Sójki skrzeczą za oknem, żebyż to sójki, ale albo Steller's Jays albo Scrub Jays, czarne w górnej połowie, niebieskie $u$ dołu, z czarnym czubem, tyle że głos jednych i drugich, złodziejskośćs ${ }^{34}$, bezczelność te same co u ich pobratymców w odległym o tysiące mil moim rodzinnym kraju. Czym jest sójkowatość? W krótkości cyklu ich życia, w powtarzalności jego przez millenia, bez wiedzy, że istnieje coś takiego jak „bycie sójką” czy „bycie Steller's Jay", jest coś zdumiewającego. ${ }^{35}$

Zarówno w wierszu Sroczość, jak w przytoczeniu z Widzeń... mamy wyraźnie do czynienia z - charakterystycznym dla całej twórczości Miłosza - pytaniem o istotę ( $w$ analizowanych przeze mnie przykładach: istotę ptaka). Teraz już jesteśmy pewni, że naiwna, dziecięca wrażliwość została bezpowrotnie utracona. Choć w zaproponowanej tutaj interpretacji Doliny Issy pokazuję, że

Tamże, s. 480.

Fragment, w którym Miłosz pisze o „złodziejskości” sójek, budzi wątpliwość, ponieważ „złodziejskość" przypisywana jest wszak innym krukowatym - srokom. Zob. A. Cattabiani Volario. Simboli, miti e misteri degli esseri alati: uccelli, insetti, creature fantastiche, Mondadori, Milano 2000, S. 309-310. 
Tomasz - skażony świadomością dorosłego Miłosza - tak naprawdę nigdy nie uzyskał prawdziwego dostępu do dzikiego ptasiego świata.

W tym kontekście jakże prawdziwie brzmi odniesienie do chłopięcych lat z Widzeń nad Zatoką San Francisco:

Będąc chłopcem miałem dosyć zajęć z tym, co biega, lata, pełza, co rośnie, czemu można się przyglądać, czego można dotknąć i nie interesowałem się słowami. [...] A jednak, na inny sposób byłem wielbicielem słów, choć nie tych układanych w zdania i frazy. Przyrodnik, kolekcjoner duszonych w wyziewach formaliny i wbijanych w szpilkę chrabąszczy, okazów roślin w zielnikach, ptasich jajek podbieranych w gąszczu za cenę podrapania twarzy i bosych nóg, byłem pewien wyjątkowej wagi moich czynności i odrzuciłbym jako zniewagę przypuszczenie, że może nie ja jedyny pośród moich rówieśników przeżywam taką namiętność. Romeo - a moją Julią była zarówno nieobjęta obfitość kształtów i barw jak jeden owad, jeden ptak przykuwający moją uwagę przez całe dnie albo tygodnie. Zakochiwałem się, co prawda, bądźmy należycie podejrzliwi, za pośrednictwem. Fascynowały mnie przede wszystkim kolorowe ilustracje w przyrodniczych książkach i atlasach, a więc nie Julia-Natura, tylko jej portret przekazany przez rysownika czy fotografa. ${ }^{36}$

Przyjrzyjmy się jeszcze fragmentowi poematu Po ziemi naszej, napisanego w Berkeley w 1961 roku:

Gdziekolwiek jesteś, owijają ciebie kolory nieba, tak jak tutaj, przenikliwe oranże i fiolety, zapach roztartego w palcach liścia tobie towarzyszy nawet we śnie, ptaki są nazwane językiem tego miejsca: towhee przyszła do kuchni, posyp trochę chleba na trawniku, przyleciały juncos.

Gdziekolwiek jesteś, dotykasz kory drzew próbując jej chropowatości innej a domowej.

Wdzięczny za wschody i zachody słońca gdziekolwiek jesteś, nie zdołasz być obcy. ${ }^{37}$ 
Doświadczenia z dzieciństwa przyczyniły się do częściowego choćby poznania dzikiego świata litewskich lasów, ale też zrodziły potrzebę dokonywania pierwszych prób systematyzacji, dotykania za pośrednictwem słów. Poeta przyznaje, że nie może uwolnić się od formuł i nazw, ale dzięki temu, że zawsze otwierał się na świat przyrody, w każdym miejscu na ziemi będzie umiał się odnaleźć, ponieważ zna rytm natury. Miłosz pokazuje, że tak naprawdę nigdy nie wkroczył do „matecznika”, zawładnęła nim bowiem konieczność klasyfikowania:

W tej woli klasyfikacji był wściekły arystotelizm, powtarzałem wczesne procedery porządkowania otaczającego nas świata, jakby prawdą było, że dzieciństwo, chłopięctwo, dojrzałość odpowiadają fazom, przez jakie przechodzi ludzkość. I dodam, że szał mój miał cechy wyraźnie samcze, wyrażała się w nim ta sama chciwość rozgraniczeń, definicji, mocniejszych niż rzeczywistość konceptów, która jednych uzbrajała w miecz, innych wtrącała do lochu i prowadziła wiernych na święte religijne wojny. ${ }^{38}$

Miłosz zdaje - można by rzec - uczciwą relację, wskazując na swoje porządkujące zapędy: interpretuje bowiem potrzebę nazywania ptaków jako próbę zawładnięcia nimi. Ale przemilcza fakt, że Tomaszowi w Dolinie Issy wkłada do ręki myśliwską broń...

Prowadząc kwerendę w Archiwum Zbigniewa Herberta w Warszawie, natrafiłam na notatki wskazujące, że Herbert planował napisać książkę zatytułowaną Rokjagnięcia. Już sam tytuł można odczytać jako krytyczne nawiązanie do Roku myśliwego Miłosza. Upewnia w tym jeden z niewielu zachowanych zapisków, mający - jak sądzę - otwierać ten nieukończony, a lepiej rzec, ledwie zaczęty, tom:

\section{Zwierzę ofiarne}

Bardzo późno, bo w lipcu 1991, kiedy zbliżały się moje 67 urodziny wiosna życia, uświadomiłem sobie, że jestem zwierzęciem ofiarnym: tytuł tej książki, który w zamierzeniu był agresywny i polemiczny w stosunku do książki Miłosza, nabrał nowego i, jak się zdaje, prawdziwego sensu. Od dzieciństwa kochałem zwierzęta dzikie, bezpańskie, cierpiące. Wielkim zaniedbaniem. ${ }^{39}$

Tamże, s. 19.

39 Zapiski oznaczone skrótem „R.).”, numeracja rzymska „VIII”, pochodzą z Archiwum Zbigniewa Herberta w Warszawie (zbiory Biblioteki Narodowej) z teczki o sygnaturze: akc. 17877, t. 1. 
Nie wiemy, w jakim kierunku miały pójść rozważania Herberta. Możemy jednak przypuszczać, że poeta planował przyjąć - charakterystyczną dla siebie $^{40}$ - głęboko empatyczną postawę. Stąd sprzeciw wobec Miłoszowego myśliwego, bez względu na to, czy słowo to odczytywać będziemy dosłownie czy metaforycznie.

\section{Abstract}

\section{Magdalena Śniedziewska}

THE INSTITUTE OF LITERARY RESEARCH OF THE POLISH ACADEMY OF SCIENCES (WARSAW) Miłosz and the Birds

Śniedziewska examines Miłosz's relationship to animals - especially birds - as it can be reconstructed from Dolina Issy and some of his poems. Fascinated with both nature and hunting, Miłosz advocates for two contradictory positions. As soon as he enters the world of hunting - portryed by Schiller as a naive perspective - and begins to observe wild animals, he undergoes a radical change. Śniedziewska argues that Tomasz, the alter ego of the young Miłosz, whose perspective is influenced by the consciousness of the mature poet, never really attains real access to the wild birds' world. Miłosz's poems about birds, however, are part of his reflections on the essence of all living creatures. The place where his thoughts about birds intersect in his prose and poems are his remarks on the problem of classification: naming as appropriation.

\section{Keywords}

Miłosz, Dolina Issy, birds, hunting, ecocriticism, nature

40 Zob. J. Kwiatkowski Imiona prostoty, w: Poznawanie Herberta, red. A. Franaszek, Wydawnictwo Literackie, Kraków 1998, s. 43: „Herbert jest poetą współczucia. Skrzywdzeni - to specjalnie uprzywilejowani podopieczni jego wierszy". 